\title{
PENGELOLAAN ANGGARAN PADA MASA PANDEMI COVID-19 DI KPPBC TMP A MARUNDA DALAM PERSPEKTIF AKUNTANSI
}

\author{
Muhammad Aripradana Wibawa ${ }^{1)}$; Puji Wibowo ${ }^{2)}$ \\ 1) aripradanawibawa@gmail.com, Direktorat Jenderal Bea dan Cukai \\ ${ }^{2)}$ puji.wibowo@pknstan.ac.id, Politeknik Keuangan Negara STAN*
}

\begin{abstract}
The Covid-19 pandemic has caused dynamics in the budget absorption process, sothat budget revisions are very crucial in determining the absorption rate and work unit operations. This study aims to measure the accuracy of KPPBC TMP A Marunda in preparing the budget and knowing the policies taken in the face of the Covid-19 pandemic. The analytical method used is a qualitative analysis by processing data through interviews, observations, and literature studies. Based on the results of data processing, the budget revision in the 2020 fiscal year was carried out with several themes, including budget revisions in terms of changing budget ceilings, revisions to budget shifts in terms of fixed budget ceilings, and administrative revisions by making budget savings during the Covid-19 pandemic, adding a special account for handling Covid-19 and revision of the minus ceiling. Budget revisions are carried out by paying attention to budget performance against realization and the amount of the budget ceiling. Budget revisions in the context of budget savings to deal with the Covid-19 pandemic are carried out by reducing budgets sourced from accounts that are considered not become a priority. The presentation of the special account for handling Covid-19 in the financial statements does not have a special segment, it is presented as goods expenditure in the budget realization report and presented as goods and services expense in the operational report.
\end{abstract}

Keywords : Budget Revision, Covid-19, Budget Realization, Customs

\begin{abstract}
Abstrak
Pandemi Covid-19 menyebabkan terjadinya dinamika dalam proses penyerapan anggaran, sehingga revisi anggaran menjadi hal yang sangat krusial dalam menentukan tingkat penyerapan dan operasional satuan kerja. Penelitian ini bertujuan untuk mengukur ketepatan KPPBC TMP A Marunda dalam melakukan penyusunan anggaran dan mengetahui kebijakan yang diambil dalam menghadapi pandemi Covid-19. Metode analisis yang digunakan adalah analisis kualitatif dengan melakukan pengolahan data melalui hasil wawancara, observasi dan studi literatur. Berdasarkan hasil pengolahan data, revisi anggaran pada tahun anggaran 2020 dilakukan dengan beberapa tema, diantaranya revisi anggaran dalam hal pagu anggaran berubah, revisi pergeseran anggaran dalam hal pagu anggaran tetap, dan revisi administrasi dengan melakukan penghematan anggaran selama masa pandemi Covid-19, melakukan penambahan akun khusus penanganan Covid-19 dan revisi pagu minus. Revisi anggaran dilakukan dengan memperhatikan kinerja anggaran terhadap realisasi dan jumlah pagu anggaran, Revisi anggaran dalam rangka penghematan anggaran untuk menghadapi pandemi Covid-19 dilakukan dengan melakukan pengurangan anggaran yang bersumber dari akun yang dianggap tidak prioritas. Penyajian terhadap akun khusus penanganan Covid-19 di laporan keuangan tidak memiliki segmen khusus, disajikan sebagai belanja barang pada laporan realisasi anggaran dan disajikan sebagai beban barang dan jasa pada laporan operasional.
\end{abstract}

Kata Kunci : Revisi Anggaran, Covid-19, Realisasi Anggaran, Bea Cukai

\section{PENDAHULUAN}

Pada tahun 2020 terjadi kejadian luar biasa yaitu pandemi Covid-19 yang berdampak kepada perekonomian Indonesia. Dampak pandemi dirasakan oleh berbagai negara dengan merevisi APBN masing-masing untuk menyediakan dana yang besar guna mengatasi wabah tersebut (Muhyidin, 2020). Pemerintah Indonesia memberikan respon dengan melakukan penyesuaian terhadap postur pendapatan dan belanja tahun anggaran 2020 dalam bentuk perubahan pada rincian besaran anggaran pendapatan negara, anggaran belanja negara, pembiayaan anggaran dan surplus atau defisit anggaran.

Kebijakan relaksasi APBN ditempuh melalui Instruksi Presiden Republik Indonesia Nomor 4 Tahun 2020, yang secara umum mengatur refocussing kegiatan, realokasi anggaran dan percepatan pelaksanaan pengadaan barang dan jasa guna mendukung penanganan virus ini. Kebijakan tersebut ditempuh untuk menghindarkan negeri ini dari jurang resesi (Sopanah dan Haikal, 2021). Hal ini pada akhirnya akan berdampak terhadap realisasi penyerapan anggaran 


\section{JURNALKU}

Volume 1 No. 2, Juni 2021

seperti belanja pegawai, belanja barang, dan belanja modal (Suyitno, 2020). Imbasnya, perubahan anggaran tersebut perlu mendapatkan perhatian penting dari sisi akuntansi.

Akuntansi anggaran berperan penting dalam setiap kebijakan yang dilakukan untuk menghadapi pandemi. Melalui perencanaan ulang atau revisi anggaran maka satuan kerja dapat melakukan penyesuaian terhadap setiap mata anggaran yang membutuhkan penyesuaian, serta menambahkan akun terkait Covid-19 serta melakukan penyesuaian terhadap rencana realisasi anggaran yang tercantum pada halaman III DIPA. Seluruh satuan kerja pengguna anggaran diminta untuk menyesuaikan dokumen DIPA untuk realokasi dana APBN guna merespon dampak wabah pandemi (Lestyowati dan Kautsarina, 2020).

Kantor Pengawasan dan Pelayanan Bea dan Cukai Tipe Madya Pabean A Marunda merupakan kantor pelayanan dibawah Direktorat Jenderal Bea dan Cukai yang berlokasi di Marunda, Jakarta Utara, dengan wilayah kerja yang mencakup Kepulauan Seribu, Jakarta Barat, Jakarta Utara kecuali Pelabuhan Tanjung Priok, dan Pos Pengawasan Bea dan Cukai yang terdiri dari 11 pos, KPPBC TMP A Marunda memiliki alokasi anggaran pada tahun anggaran 2019 sebesar Rp18.630.735.000. Dengan anggaran yang besar dan wilayah kerja yang luas serta bervariasi, maka sangat dimungkinkan terjadi dinamika dalam proses penyerapan anggaran, sehingga revisi anggaran menjadi hal yang sangat krusial dalam menentukan tingkat penyerapan dan operasional satuan kerja. Disamping itu, Covid-19 berdampak pula terhadap penerimaan pajak ekspor (Suparman, 2021). Hal ini relevan untuk diamati mengingat pungutan tersebut menjadi tugas dan fungsi Direktorat Jenderal Bea dan Cukai

Penyusunan anggaran pada tingkat satuan kerja didasarkan kepada kebijakan pagu alokasi anggaran yang telah ditetapkan, dengan penetapan baseline pagu anggaran dilakukan dengan melakukan penyusunan terhadap RKA-KL oleh satuan kerja dengan menyampaikan berkas-berkas diantaranya adalah Rincian Kertas Kerja (RKK) Satker, Rencana Kerja dan Anggaran (RKA) satker Form A, Form B, Form C, Form D, Term of Reference (TOR), Rincian Anggaran Belanja (RAB) dan data pendukung lainnya serta Arsip Data Komputer (ADK) usulan RKA-K/L.

Bersamaan dengan penyusunan RKA-K/L. Satuan kerja melakukan penyusunan Rencana Penarikan Dana (RPD) setiap bulannya berdasarkan anggaran yang telah diajukan, yang kemudian tertuang di dalam halaman III DIPA. Kemudian satuan kerja melakukan realisasi terhadap anggaran yang telah diberikan berdasarkan rencana penarikan yang sudah ditetapkan.

Penelitian terdahulu yang berkaitan dan juga meneliti mengenai anggaran antara lain penelitian yang diteliti oleh Effendi dan Imron (2019). Mereka menyatakan bahwa prinsip efisiensi tidak dapat diterapkan dalam pengalokasian anggaran pada suatu kementerian atau lembaga karena efisiensi alokasi berarti output anggaran dapat dikategorikan sebagai efisien ketika sumber daya atau uang yang digunakan seminimal mungkin.

Di sisi lain, Sukarta et al. (2017) menyatakan bahwa revisi anggaran dapat memberikan pengaruh yang positif pada efektivitas pengelolaan anggaran. Hasil pengujian terhadap hipotesis memberikan simpulan bahwa peningkatan kualitas anggaran melalui revisi anggaran berpengaruh pada peningkatan efektivitas pengelolaan anggaran. Sementara itu, Alim (2008) menyatakan bahwa revisi anggaran berpengaruh terhadap peningkatan kinerja manajerial dan memberikan dampak signifikan, peningkatan kinerja manajerial juga dapat ditingkatkan melalui evaluasi anggaran dengan berorientasi pada proses pencapaian anggaran, bukan dengan menggunakan target anggaran.

Namun demikian, penelitian terdahulu tersebut belum ada yang menyentuh perspektif akuntansi anggaran selama masa pandemi. Studi ini dibuat untuk melengkapi gap penelitian dimaksud. Penelitian ini penting dilakukan untuk melihat dampak kebijakan revisi anggaran dalam pelaporan keuangan sebuah satuan kerja melalui pendekatan studi kasus. 


\section{JURNALKU}

Volume 1 No. 2, Juni 2021

\section{KAJIAN PUSTAKA \\ Stewardship Theory}

Donaldson \& Davis (1991) mengemukakan gagasan stewardship theory yang bermakna sebagai situasi dimana para manajer termotivasi oleh kepentingan organisasi sebagai target utama, bukan oleh tujuan individu. Murwaningsari (2009) juga menjelaskan bahwa stewardship theory dibuat melalui asumsi filosofis bahwa manusia memiliki sifat bertanggung jawab, berintegritas serta dapat dipercaya.

Dalam teori stewardship kepercayaan merupakan konsep inti, dimana seorang manajer atau pimpinan akan melakukan hal sesuai kepentingan bersama karena steward akan melakukan pertimbangan rasional untuk mencapai tujuan organisasi, serta jika ada perbedaan pendapat, maka akan cenderung untuk mencari cara akan dapat diselesaikan secara bersama-sama daripada menentang perbedaan pendapat tersebut.

Teori stewardship dalam studi ini relevan digunakan dalam menjelaskan peran para pimpinan untuk mengawal efektivitas organisasi dengan memperhatikan ketersediaan anggaran. Pemimpin instansi pemerintah selama masa pandemi diharapkan dapat mengedepankan kepentingan bersama melalui kebijakan relaksasi penganggaran yang lebih tepat.

\section{Institutional Theory}

Teori institusional memberikan pemahaman bahwa organisasi akan berusaha untuk menjaga eksistensinya dengan cara menunjukan kepada publik bahwa organisasi bersifat legal, merupakan entitas yang sah dan layak untuk diberikan dukungan. DiMaggio dan Powell (1983) berpendapat bahwa organisasi cenderung berusaha menyesuaikan diri pada harapan eksternal atau harapan sosial dengan syarat organisasi mengutamakan legitimasi. Organisasi yang mengutamakan legitimasi akan memiliki isomorfisme dengan organisasi publik lain.

Isomorfisme merupakan proses penyesuaian unit dalam suatu populasi untuk menyerupai unit yang lain dalam menghadapi kondisi lingkungan yang sama. Teori institusional dalam organisasi memberikan gambaran mengenai perubahan organisasi yang menjadi lebih serupa karena tekanan institusional, baik dikarenakan adanya koersif (coercive), normatif (normative), dan mimetik (mimetic).

Teori institusional ini berkaitan dengan bagaimana respon instansi pemerintah dalam menghadapi gejolak ekonomi yang berdampak pada postur APBN. Dalam hal ini teori institusional memberikan gambaran bagaimana sebuah organisasi pemerintahan melakukan adaptasi anggaran, apakah dilandasi dengan penuh kesadaran atau melalui upaya enforcement dari pihak luar.

\section{Attribution Theory}

Teori atribusi memberikan pemahaman mengenai reaksi individu terhadap kejadian yang terjadi di lingkungan mereka, dengan mengambil kesimpulan atas reaksi atau keputusan yang diambil seseorang dalam menghadapi peristiwa tersebut.Teori atribusi merupakan teori yang mempelajari perilaku dan menjelaskan bagaimana proses seseorang menafsirkan atau mengintrepretasikan suatu peristiwa, alasan atau sebab hal yang dilakukannya (Heider, 1958).

Selanjutnya, Heider juga berpendapat bahwa pengaruh yang berasal dari kekuatan internal dan eksternal dapat menentukan perilaku manusia, kekuatan internal seperti kelelahan, kemampuan, pengetahuan dan skill atau kekuatan eksternal seperti lingkungan kerja, cuaca dan peraturan yang berlaku di lingkungan dinyatakan dapat mempengaruhi evaluasi kinerja individu dan keputusan yang diambil, seperti bagaimana seorang atasan memperlakukan bawahannya, atau bagaimana seorang atasan mengambil keputusan mengenai kebijakankebijakan strategis yang harus diambil. Senada dengan hal tersebut, Robbins dan Judge (2008) berpendapat bahwa perilaku individu dapat disebabkan oleh pengaruh internal atau pengaruh 


\section{JURNALKU}

Volume 1 No. 2, Juni 2021

eksternal. Teori atribusi penting untuk mengamati perilaku individu baik sebagai atasan atau bawahan dalam menyikapi kebijakan relaksasi anggaran di masa pandemi Covid-19.

\section{Konsep Akuntansi Pemerintah}

Akuntansi pemerintah merupakan suatu aktivitas untuk menyediakan informasi keuangan pemerintah yang didasarkan oleh proses pencatatan, klasifikasi dan proses ikhtisar transaksi keuangan yang dilakukan oleh pemerintah, yang berpedoman kepada standar akuntansi keuangan pemerintah (SAP). Standar ini diatur melalui Peraturan Pemerintah Republik Indonesia Nomor 71 Tahun 2010 Tentang Standar Akuntansi Pemerintahan.

Akuntansi pemerintah merupakan pengembangan dari akuntansi dan audit pada sektor komersial. Perbedaanya terletak pada konsep dasar, prosedur dan standar yang disesuaikan dengan kebutuhan dan lingkungan pengguna laporan keuangan.

Beberapa karakteristik akuntansi pemerintah yang penting antara lain meliputi: orientasi, kepemilikan, kontribusi, keputusan. Sebagai sebuah organisasi publik, pemerintah tidak beroritentasi untuk mencari keuntungan. Hal ini ditunjukkan oleh pendapatan yang dipungutnya merupakan amanat peraturan perundangan dan dimanfaatkan untuk kesejahteraan bersama. Organisasi pemerintah juga tidak dimiliki atas dasar saham karena merupakan kepemilikan kolektif dan konstituen. Kontribusi para stakeholder atau masyarakatnya umumnya tidak memberikan manfaat langsung bagi para pembayarnya. Selanjutnya, keputusan dan kebijakan yang dibuat penuh nuansa politis karena harus melalui persetujuan dewan perwakilan rakyat. Keputusan dibuat secara terbuka sehingga akuntansi dan laporan-laporan lain yang terkait dengan pelaksanaan dapat dipertanggungjawabkan.

Meskipun karakteristik akuntansi pemerintah berbeda dengan swasta, secara umum terdapat beberapa kesamaan yaitu : (i) memberikan informasi atas posisi keuangan dan hasil operasi; (ii) mengikuti prinsip-prinsip dan standar akuntansi yang diterima umum; (iii) bersama-sama mengembangkan prinsip-prinsip dan standar akuntansi; dan (iv) menggunakan system bagan perkiraan standar (Hasanah dan Fauzi, 2016:3).

Pemerintah menjalankan kebijakan pelayanan publik berbasis dukungan penganggaran dari APBN. Anggaran merupakan rencana kerja yang dinyatakan secara kuantitatif, diukur dalam satuan moneter dan satuan ukuran lain yang mencakup waktu satu tahun (Mulyadi, 2001). Menurut Governmental Accounting Standard Board (GASB) anggaran adalah rencana operasi keuangan yang mencakup estimasi pengeluaran yang diusulkan dan sumber pendapatan yang diharapkan untuk membiayai pengeluaran dalam periode waktu tertentu.

Tujuan penganggaran pemerintah antara lain untuk memberikan pernyataan mengenai sasaran pemerintah secara jelas dan formal. Aspek penganggaran juga mengomunikasikan sasaran kerja atau program pemerintah kepada pihak terkait sehingga rencana anggaran dapat dimengerti, didukung dan dilaksanakan dengan baik. Disamping itu, anggaran dapat memberikan rencana aktivitas secara terperinci. Selanjutnya, anggaran disusun dengan tujuan untuk mengoordinasikan cara atau metode yang akan digunakan untuk memaksimalkan sumber daya. Pada akhirya, anggaran juga dipakai sebagai alat ukur dan kendali kinerja pelaksana anggaran secara individu dan kelompok.

Di dalam PSAP juga diatur mengenai fungsi anggaran pemerintah yang terdiri dari 6 elemen diantaranya, fungsi perencanaan, pengawasan, koordinasi, penilai, distribusi, dan stabilisasi. Ditinjau dari sisi perencanaan, anggaran berfungsi sebagai rencana tindak lanjut atas rencana kegiatan pemerintah, serta besaran biaya untuk melaksanakan kegiatan dan pendapatan yang diperoleh melalui kegiatan yang dilakukan. Dalam perspektif fungsi pengawasan, anggaran berfungsi sebagai alat untuk mengawasi kinerja pemerintah karena mengatur secara detail mengenai target pendapatan, pengeluaran dan bentuk pertanggung jawabannya kepada publik. Adapun dalam hal yang berkaitan dengan fungsi koordinasi, anggaran berfungsi sebagai 


\section{JURNALKU}

Volume 1 No. 2, Juni 2021

alat koordinasi antar unit pemerintahan, karena segala sesuatu yang dilakukan berdasarkan anggaran.

Selanjutnya, anggaran juga berfungsi sebagai penilai yaitu untuk menilai keberhasilan pemerintah dalam memanfaatkan anggaran. Kebijakan yang berkaitan dengan penggunaan anggaran negara diharapkan memperhatikan distribusi yang adil dan patut. Yang tidak kalah penting dari fungsi anggaran adalah fungsi stabilisasi yang diembannya, karena anggaran dapat dipergunakan sebagai alat pemerintah untuk menjaga keseimbangan perekonomian.

Anggaran merupakan alat yang sangat baik untuk digunakan sebagai alat pengendali, karena didalam anggaran telah tercantum pos-pos pengeluaran dan jumlah dana yang dapat dikeluarkan apakah penggunaanya telah mengacu pada tujuan negara untuk mewujudkan kesejahteraan masyarakat dan percepatan pembangunan.

Anggaran disusun berdasarkan pendekatan berbasis kinerja, sehingga target capaian kinerja ditetapkan sebelum melakukan penetapan terhadap besaran anggaran, dan disusun sesuai skala prioritas pemerintah dan derajat kepentingan publik, sehingga diharapkan anggaran yang disusun pemerintah memiliki dampak yang besar terhadap kesejahteraan masyarakat.

Terdapat empat cara yang dapat dilakukan untuk melakukan pengendalian angggaran. Pertama, melakukan perbandingan terhadap kinerja aktual dengan kinerja yang telah dianggarkan. Kedua, menghitung selisih anggaran (favorable atau unfavorable). Ketiga, mencari penyebab yang bersifat controllable atau bersifat uncontrollable atas suatu varians yang terjadi. Keempat, melakukan revisi anggaran berupa revisi standar biaya atau target anggaran pada tahun berikutnya.

Berdasarkan Peraturan Menteri Keuangan Nomor 102/PMK.02/2018 Tentang Klasifikasi Anggaran, komponen APBN terdiri dari anggaran belanja negara, pendapatan negara dan pembiayaan anggaran. Menteri atau pimpinan lembaga terkait selaku pengguna anggaran, atas bagian yang dikuasainya diwajibkan menyusun Rencana Kerja dan Anggaran Kementerian/Lembaga (RKA-K/L). Penyusunan (RKA-K/L) dilakukan dengan sistem penganggaran yang terdiri dari penganggaran berbasis kinerja, kerangka pengeluaran jangka menengah dan penganggaran terpadu.

Adapun jika kita mengacu pada ketentuan pasal 11 ayat (5) Undang-Undang Nomor 17 Tahun 2003 tentang Keuangan Negara, klasifikasi belanja negara terbagi atas klasifikasi menurut organisasi, fungsi dan jenis belanja. Klasifikasi anggaran merupakan pengelompokan anggaran belanja negara yang digunakan dalam penyusunan dan penyajian informasi APBN.

Klasifikasi organisasi merupakan pengelompokan anggaran belanja yang didasari oleh struktur organisasi kementerian atau lembaga dan bendahara umum negara, Bagian anggaran merupakan klasifikasi berdasar organisasi yang disusun menurut nomeklatur kementerian atau lembaga. Oleh karena itu setiap Kementerian/Lembaga mempunyai kode bagian anggaran tersendiri. Sesuai ketentuan Peraturan Menteri Keuangan Nomor 102/PMK.02/2018, terdapat 87 Kementerian/Lembaga yang terdaftar sebagai pengguna anggaran dan memiliki bagian anggaran. Kementerian keuangan memiliki kode bagian anggaran 015.

Anggaran juga disusun dengan pendekatan fungsi. Klasifikasi fungsi didasari oleh fungsi pemerintahan yang dilaksanakan oleh menganalisis fungsi mana yang memiliki serapan alokasi anggaran paling banyak dan fungsi mana yang hanya sedikit menyerap alokasi anggaran. Indonesia menerapkan klasifikasi anggaran yang mengacu pada Classification of the Functions of Governement (COFOG), kemudian dilakukan kompilasi terhadap alokasi anggaran tersebut dan dijadikan sebagai data statistik penyusunan anggaran yang mengikuti standar internasional dan dipublikasikan oleh PBB. Data tersebut dapat digunakan sebagai alat analisis untuk memberikan gambaran mengenai perkembangan suatu negara berdasar fungsi, subfungsi dan program yang dilakukan, sehingga anggaran yang sudah disusun dapat dibandingkan dengan negara lain yang juga mengacu pada COFOG. 


\section{JURNALKU}

Volume 1 No. 2, Juni 2021

Klasifikasi anggaran menurut fungsi yang berlaku saat ini adalah (i) pelayanan umum; (ii) pertahanan, (iii) ketertiban dan keamanan, (iv) ekonomi; (v) lingkungan hidup, (vi) perumahan dan fasilitas umum, (vii) kesehatan, (viii) pariwisata dan budaya; (ix) agama, (x) pendidikan dan (xi) perlindungan sosial. Fungsi dan subfungsi berkaitan dengan rencana kegiatan masing-masing kementerian atau lembaga dan disesuaikan dengan tugas pokok dan fungsinya, sehingga dalam satu program dapat digunakan beberapa fungsi.

Pendekatan berikutnya terkait pengelompokan belanja adalah menurut jenis. Klasifikasi jenis belanja adalah pengelompokan anggaran yang berdasar jenis belanja yang terdapat pada kementerian atau lembaga dan bendahara umum negara, prinsip akuntansi yang digunakan mengacu pada manual Government Finance Statistics 2001 (GFS 2001 Manual).

Jenis belanja digunakan sebagai klasifikasi dalam proses penyusunan, pelaksanaan dan pertanggungjawaban atau pelaporan anggaran. Penggunaan jenis belanja bertujuan untuk mengetahui distribusi alokasi anggaran ke dalam jenis belanja serta memberikan fleksibilitas penyusunan anggaran dengan menggunakan akun dengan kode 2 digit yang menunjukan jenis belanja, jika digunakan dalam level yang lebih detail maka harus menggunakan kode akun yang sesuai dengan kaidah penganggaran yang berlaku. Terdapat 8 jenis klasifikasi anggaran menurut jenis belanja yaitu: (i) belanja pegawai, (ii) belanja barang dan jasa, (iii) belanja modal, (iv) belanja pembayaran kewajiban utang, (v) belanja subsidi (vi) belanja hibah, (vii) belanja bantuan sosial, dan (viii) belanja lain-lain.

Revisi anggaran merupakan hal yang tidak bisa dihindari selama masa pandemi. Kebijakan work from home yang dicetuskan untuk seluruh intansi pemerintah telah mengubah pola kegiatan birokrasi yang berdampak pada penyerapan anggaran. Optimalisasi penyerapan anggaran perlu mendapatkan dukungan berupa revisi anggaran (Atmodjo dan Akhmadi, 2021).

Salah satu kebijakan yang ditempuh Pemerintah terkait revisi anggaran adalah pengalokasian belanja dalam rangka penganganan pandemi Covid-19 berdasarkan klasifikasi akun khusus Covid-19. Atmodjo dan Akhmadi (2021) selanjutnya menjelaskan bahwa berdasarkan Peraturan Menteri Keuangan No. 38/PMK.02/2020, pengalokasian Belanja Penanganan Pandemi Covid-19 pada akun-akun khusus dalam rangka Covid-19 dilakukan untuk mempermudah proses perencanaan, koordinasi, monitoring dan evaluasi kinerja kegiatan. Disamping itu, kebijakan tersebut juga untuk mempermudah proses pergeseran anggaran antarunit organisasi, antarfungsi, dan/atau antarprogram dalam rangka merespon gejolak Covid-19.

Penelitian mengenai anggaran dalam organisasi pemerintah telah dilakukan oleh beberapa cendekia terdahulu. Zamaro (2019) menyatakan bahwa Indonesia belum sepenuhnya menggunakan pendekatan penganggaran yang berbasis kinerja, karena proyeksi awal penganggaran top-down khususnya pada belanja operasional masih menggunakan alokasi dan realisasi anggaran pada periode sebelumnya, hal ini menunjukan penganggaran cenderung bersifat pendekatan incremental. Pada pendekatan kinerja seharusnya proyeksi penganggaran dibuat berdasar kebutuhan pada setiap kegiatan dan program yang kemudian dicerminkan melalui output yang dihasilkan melalui kegiatan dan program tersebut.

Alim (2008) dalam penelitiannya menyatakan bahwa revisi anggaran dapat dipertimbangan untuk meningkatkan kinerja pada kondisi khusus dan evaluasi yang berbasis proses pencapaian anggaran. Komponen anggaran tidak harus dipaksakan untuk dapat sesuai dengan tingkat kesulitan anggaran, namun jika ada kesesuaian antara sasaran dan komponen anggaran maka akan meningkatkan kinerja manajerial.

Selanjutnya Walidi (2017) dalam penelitiannya menyatakan bahwa penyusunan standar biaya menunjukan peningkatan yang membaik dari tahun ke tahun, hal ini merupakan modal dasar agar standar biaya dapat mewujudkan allocative efficiency dan operational efficiency dalam proses penganggaran. 


\section{JURNALKU}

Volume 1 No. 2, Juni 2021

Sukarta et al (2017) berpendapat bahwa peningkatan kompetensi sumber daya manusia dapat meningkatkan efektivitas pengelolaan anggaran. Hal ini dapat dilakukan dengan cara menambah diklat terkait pengelolaan anggaran, penambahan sumber daya manusia berkualifikasi pendidikan akuntansi, mempertahankan pengelola anggaran yang berpengalaman, dan pemanfaatan teknologi dalam proses pengelolaan anggaran.

Yeyen (2013) menyatakan bahwa revisi anggaran memiliki dampak yang positif terhadap efektivitas pencapaian anggaran. Adapun Sirat (2017) dalam penelitiannya menemukan bahwa salah satu tantangan terbesar proses penganggaran adalah penentuan besaran alokasi.

Berdasarkan hasil penelitian terdahulu yang sudah disampaikan, beberapa isu penting terkait anggaran yang telah dilakukan diantaranya adalah terkait isu proses proyeksi anggaran yang belum sepenuhnya sejalan dengan teori penganggaran berbasis kinerja, kesesuaian antar komponen anggaran dengan sasaran anggaran, pengaturan standar biaya, peningkatan kompetensi sumber daya manusia pengelola anggaran serta efektivitas revisi anggaran. Isu terkait akuntansi anggaran selama masa transisi seperti pandemi Covid-19 belum banyak diulas oleh para peneliti. Dengan demikian, penelitian ini berupaya memberikan kontribusi berupa menemukan bukti empiris mengenai respon organisasi pemerintah dalam penganggaran selama masa pandemi.

\section{METODE}

Metode penelitian yang digunakan adalah metode kualitatif deskriptif dengan menggunakan pendekatan studi kasus. Saryono (2010) Penelitian kualitatif adalah penelitian yang digunakan untuk menyelidiki, menemukan, menggambarkan, dan menjelaskan kualitas atau keistimewaan dari pengaruh sosial yang tidak dapat dijelaskan, diukur atau digambarkan melalui desain kuantitatif.

Objek penelitian adalah KPPBC TMP A Marunda untuk periode anggaran tahun 2020. Dalam penelitian ini dilakukan wawancara dengan berbagai pihak yang terlibat dalam penganggaran. Wawancara dengan narasumber tersebut dilakukan dengan melakukan tanya jawab secara langsung maupun secara virtual kepada kepala subaggian umum, staff keuangan pada KPPBC TMP A Marunda untuk mendapatkan informasi yang dibutuhkan terkait dengan proses penyusunan anggaran, kebijakan yang diambil dalam rangka revisi anggaran untuk menangani pandemi Covid-19 serta penyajian dan pengungkapan realisasi anggaran selama masa pandemi Covid-19.

Peneliti juga melakukan observasi data dengan cara mengamati dan mengakses aplikasi terkait anggaran yaitu aplikasi SAKTI dan OM-SPAN dan realisasi belanja melalui laporan keuangan tahun anggaran 2020 dengan didampingi oleh staff keuangan pada KPPBC TMP A Marunda.

\section{HASIL DAN PEMBAHASAN}

\section{Proses Penyusunan Anggaran}

Penyusunan anggaran dimulai ketika pemerintah melalui Kementerian Perencanaan Pembangunan Nasional/Badan Perencanaan Pembangunan Nasional dan Kementerian Keuangan menyerahkan pagu indikatif yang dituangkan dalam rencana kerja pemerintah kepada kementerian atau lembaga. Dengan berpedoman pada pagu indikatif maka kementerian atau lembaga dapat menyusun rencana kerja tahunan.

Dengan didasari oleh kapasitas fiskal, rencana kerja dan besaran pagu indikatif, Menteri Keuangan menetapkan pagu anggaran untuk setiap kementerian atau lembaga untuk digunakan sebagai dasar penyusunan rencana kerja anggaran, dengan memperhatikan hasil evaluasi kinerja kementerian atau lembaga. 


\section{JURNALKU}

Volume 1 No. 2, Juni 2021

Kantor Pengawasan dan Pelayanan Bea dan Cukai Tipe Madya Pabean A Marunda selaku satuan kerja di bawah Direktorat Jenderal Bea dan Cukai menyusun rencana kerja anggaran setelah mendapatkan pagu anggaran atau baseline yang ditetapkan oleh kantor pusat Direktorat Jenderal Bea dan Cukai. pada tahap pertama Kantor Pengawasan dan Pelayanan Bea dan Cukai Tipe Madya Pabean A Marunda melakukan salah satu fungsi anggaran yaitu fungsi perencanaan dengan cara menyusun dokumen pendukung rencana kerja anggaran yaitu term of reference (TOR)/kerangka acuan kerja; rincian anggaran biaya (RAB); Rencana Kerja Anggaran (RKA); rincian kertas kerja (RKK); dan data pendukung anggaran lainnya.

Term of reference (TOR)/Kerangka Acuan Kerja (KAK) merupakan dokumen yang memberikan informasi mengenai penjelasan dan gambaran secara umum mengenai output yang akan dilaksanakan kementerian atau lembaga sesuai dengan fungsi dan tugasnya. Di dalam term of reference/kerangka acuan kerja tercakup latar belakang, indikator keluaran, maksud dan tujuan, pelaksanaan kegiatan, jadwal kegiatan, pelaksana dan penanggungjawab kegiatan, dan biaya kegiatan. Penyusunan term of reference/kerangka acuan kerja tahun anggaran 2020 menggunakan pendekatan penganggaran dengan acuan Kerangka Pengeluaran Jangka Menengah (Medium Term Expenditure Framework), penerapan anggaran secara terpadu (Unified Budget) dan penerapan anggaran berdasar kinerja (Performance Based Budgeting). Seluruh proses rencana penganggaran telah sesuai dengan standar biaya yang berlaku pada tahun anggaran 2020.

Fungsi penyusunan KAK diantaranya dipergunakan sebagai sumber informasi bagaimana tahapan dan pelaksanaan untuk mencapai output, alat bagi pimpinan untuk melakukan monitoring dan pengendalian program atau kegiatan yang dilaksanakan seluruh pegawai, serta memudahkan dalam pembuktian dan pemeriksaan terkait realisasi kegiatan.

Rincian anggaran biaya merupakan pendukung KAK yang menjelaskan tahapan pelaksanaan, besaran biaya dari setiap komponen yang merupakan tahapan pencapaian output kegiatan. Rincian anggaran belanja berfungsi untuk menyediakan informasi terperinci dari komponen biaya yang diperkirakan akan digunakan dalam term of reference atau kerangka acuan kerja. Rincian anggaran belanja juga berfungsi sebagai alat untuk menghitung total anggaran yang diperlukan untuk menyelesaikan suatu output dan mengidentifikasi komponen biaya utama dan pendukung.

Selanjutnya, Rencana Kerja Anggaran (RKA) merupakan dokumen yang berisi program dan kegiatan satuan kerja, menjabarkan rencana kerja dan rencana strategis dalam satu tahun anggaran, serta jumlah anggaran yang dibutuhkan dalam pelaksanaannnya.

Penyusunan RKA bertujuan untuk menyempurnakan rencana kerja serta mempermudah pengawasan dalam kegiatan operasional, serta beberapa tujuan lainnya yaitu sebagai dasar yuridis dalam penggunaan dana; sebagai pembatas jumlah dana atau anggaran yang dapat dipergunakan; dan sebagai alat untuk melakukan pengawasan dalam kegiatan operasional dan merinci sumber anggaran yang digunakan dan jenis penggunaan anggaran; serta untuk menganalisa dan mempersiapkan revisi atau perubahan atas rencana kerja sehingga dapat mencapai tujuan yang diharapkan dengan hasil yang maksimal.

Dokumen penting lainnya dalam proses penyusunan anggaran adalah rincian kertas kerja yang merupakan rincian dari rencana kerja anggaran satuan kerja, pada rincian kertas kerja terdapat informasi mendetail dari satuan kerja, program, kegiatan, keluaran (output), suboutput, komponen, subkomponen, akun dan detail item. Berdasarkan pengamatan penulis atas dokumen RKA-KL satker KPPBC TMP A Marunda, berikut informasi penting rincian anggaran. 
Tabel 1. Struktur Rincian Kertas Kerja Satuan Kerja (Parsial)

\begin{tabular}{ll}
\hline Nama Item & Uraian Program/Kegiatan \\
\hline Satuan Kerja & Kantor Pengawasan Dan Pelayanan BC Marunda (447532) \\
\hline Program & $\begin{array}{l}\text { Program Pengawasan, Pelayanan, dan Penerimaan di Bidang } \\
\text { Kepabeanan dan Cukai (015.05.13) }\end{array}$ \\
\hline Kegiatan & $\begin{array}{l}\text { Pelayanan, dan Penerimaan di Bidang Pelaksanaan Pengawasan, } \\
\text { Pelayanan dan Penerimaan di daerah (1681) }\end{array}$ \\
\hline $\begin{array}{l}\text { Keluaran } \\
\text { Output) }\end{array}$ & Pelayanan Kepabeanan dan Cukai Daerah (1681.001) \\
\hline Suboutput & Tanpa suboutput (1681.001.001) \\
\hline Komponen & Pemeriksaam Kepabeanan dan Cukai (051) \\
\hline Subkomponen & Tanpa subkomponen (A) \\
\hline Akun & Belanja Barang Non Operasional Lainnya (521219) \\
\hline Detail / Item & Pemusnahan Barang Dalam Rangka Pelayanan \\
\hline
\end{tabular}

Sumber: RKA-KL Satker KPPBC TMP A Marunda

Daftar Isian Pelaksanaan Anggaran (DIPA) adalah dokumen yang berisikan pelaksanaan anggaran yang disusun oleh kuasa pengguna anggaran dan disahkan oleh Direktur Jenderal Perbendaharaan atas nama Menteri Keuangan, berfungsi sebagai dasar untuk mencairkan dana APBN dan melakukan kegiatan yang mengakibatkan pengeluaran APBN, serta dapat dipergunakan sebagai alat pengendali, pelaksanaan, pelaporan di mana Pagu dalam DIPA merupakan batasan pengeluaran tertinggi.

\section{Daftar Isian Pelaksanaan Anggaran}

Daftar Isian Pelaksanaan Anggaran (DIPA) adalah dokumen yang berisikan pelaksanaan anggaran yang disusun oleh kuasa pengguna anggaran dan disahkan oleh Direktur Jenderal Perbendaharaan atas nama Menteri Keuangan, berfungsi sebagai dasar untuk mencairkan dana APBN dan melakukan kegiatan yang mengakibatkan pengeluaran APBN, serta dapat dipergunakan sebagai alat pengendali, pelaksanaan, pelaporan di mana Pagu dalam DIPA merupakan batasan pengeluaran tertinggi.

Tabel 2. DIPA Petikan TA 2020 (dalam ribuan Rupiah)

\begin{tabular}{|c|c|c|c|c|c|}
\hline \multirow[b]{2}{*}{ Kode } & \multirow[b]{2}{*}{ Uraian } & \multicolumn{4}{|c|}{ Belanja } \\
\hline & & Pegawai & Barang & Modal & Total \\
\hline 447532 & $\begin{array}{l}\text { Kantor Pengawasan dan Pelayanan BC } \\
\text { Marunda }\end{array}$ & 9.157 .209 & 9.705 .150 & 802.408 & 19.664 .767 \\
\hline 1681.001 & $\begin{array}{l}\text { Pelayanan Kepabeanan dan Cukai di } \\
\text { daerah }\end{array}$ & & 3.409 .080 & & \\
\hline 1681.002 & $\begin{array}{l}\text { Pelayanan Kepabeanan dan Cukai di } \\
\text { daerah }\end{array}$ & & 447.600 & & \\
\hline 1681.951 & $\begin{array}{l}\text { Layanan Sarana dan Prasaranan } \\
\text { Internal }\end{array}$ & & & 802.408 & \\
\hline 1681.994 & Layanan Perkantoran & 9.157 .209 & 5.848 .470 & & \\
\hline
\end{tabular}

Sumber: DIPA BP Batam Tahun 2017-2019

\section{Revisi Anggaran}

Revisi anggaran adalah perubahan rincian anggaran yang ditetapkan berdasarkan APBN Tahun Anggaran 2020 dan disahkan dalam DIPA tahun anggaran 2020. Menurut Peraturan Menteri Keuangan Nomor 39/PMK.02/2020 tentang tata cara revisi anggaran tahun anggaran 2020, revisi anggaran terdiri atas (i) revisi anggaran dalam hal pagu anggaran berubah; (ii) revisi anggaran dalam hal pagu anggaran tetap; (iii) revisi administrasi; (iv) perubahan atas Undang-Undang mengenai APBN tahun anggaran 2020; dan (v) perubahan atas kebijakan prioritas pemerintah yang telah ditetapkan dalam Undang-Undang mengenai APBN tahun anggaran 2020 dan/atau Undang-Undang mengenai perubahan atas Undang-Undang mengenai APBN tahun anggaran 2020, termasuk kebijakan pemotongan, penghematan anggaran, dan/atau self blocking. 
Revisi anggaran diperlukan karena dalam satu tahun anggaran, rencana penggunaan anggaran yang tertuang didalam rencana kerja atau POK (Petunjuk Operasional Kegiatan) dapat menjadi tidak sama dengan pelaksanaannya, dapat disebabkan oleh efektivitas pelaksanaan anggaran, efisiesi ataupun perubahan kebijakan pemerintah. Oleh karena itu revisi anggaran menjadi suatu hal yang sangat diperlukan untuk tetap menjaga kualitas penggunaan anggaran.

\section{Revisi Anggaran Tahun 2020 Sebelum Pandemi}

Berdasarkan data yang kami amati, Kantor Pengawasan dan Pelayanan Bea dan Cukai Tipe Madya Pabean A Marunda melakukan revisi anggaran yang pertama kali pada bulan Februari 2020, dengan tema revisi pergeseran anggaran dalam hal pagu anggaran tetap dan revisi administrasi.

Keperluan satuan kerja untuk melakukan revisi adalah karena terdapat pergeseran anggaran pada komponen 002 atau pada belanja barang karena terdapat perubahan rencana penarikan dana, sesuai dengan kebijakan kuasa pengguna anggaran untuk mengubah anggaran pada komponen operasional dan pemeliharaan kantor.

Permasalahan selanjutnya adalah diperlukannya penyesuaian pada Halaman III DIPA berupa rencana penarikan dana. Hal ini dilakukan untuk menjalankan fungsi anggaran sebagai perencanaan di mana revisi berupa rencana penarikan dana merupakan batasan untuk melakukan pengeluaran.

Tabel 3. Perubahan pada Halaman III DIPA Revisi 1 (dalam ribuan Rupiah)

\begin{tabular}{lrrrrrr}
\hline \multirow{2}{*}{$\begin{array}{c}\text { Rencana } \\
\text { Penarikan }\end{array}$} & \multicolumn{2}{c}{ Belanja Pegawai (51) } & \multicolumn{2}{c}{ Belanja Barang (52) } & \multicolumn{2}{c}{ Belanja Modal (53) } \\
\cline { 2 - 7 } & \multicolumn{1}{c}{ DIPA Awal } & Revisi 1 & \multicolumn{1}{c}{ DIPA Awal } & Revisi 1 & DIPA Awal & Revisi 1 \\
\hline Januari & 740.690 & 740.690 & 454.438 & 401.493 & & \\
\hline Februari & 740.690 & 740.690 & 565.897 & 611.536 & & \\
\hline Maret & 740.690 & 740.690 & 1.136 .721 & 756.690 & 751.908 & 137.300 \\
\hline April & 740.690 & 740.690 & 843.824 & 754.990 & & \\
\hline
\end{tabular}

Sumber: DIPA Revisi 1 KPPBC TMP A Marunda 2020

Kuasa pengguna anggaran (KPA) mengambil kebijakan untuk merevisi rencana penarikan belanja barang dengan mengurangi rencana penarikan dana pada bulan Januari 2020 dan menambahkan rencana penarikan dana pada bulan Februari 2020, hal ini disebabkan pada awal tahun anggaran kegiatan yang dilaksanakan belum optimal, sehingga pelaksanaan kegiatan akan lebih banyak dilakukan pada bulan Februari 2020.

Revisi kedua dilakukan pada bulan April 2020, dengan kembali melakukan penyesuaian pada Halaman III DIPA, karena diperlukan antisipasi atas perubahan kebutuhan penarikan dana dan prioritas program yang akan dilakukan serta untuk meningkatkan efektivitas, capaian kinerja dan optimalisasi penggunaan anggaran. Selanjutnya dilakukan perubahan pejabat perbendaharaan dengan pertimbangan terjadinya Perubahan Kebijakan/Penugasan Baru Pejabat Perbendaharaan.

KPA melakukan perubahan rencana penarikan dengan mengurangi rencana penarikan dana belanja pegawai dan belanja barang pada bulan April 2020 dikarenakan adanya adaptasi terhadap sistem baru new normal dengan pembagian sistem kerja baru berupa work from home dan work form office sehingga banyak target realisasi yang tidak dapat dilakukan.

Kebijakan yang diambil oleh kuasa pengguna anggaran untuk melakukan revisi halaman III DIPA dan revisi komponen 002 memiliki kesesuaian dengan teori institusional karena Kantor Pengawasan dan Pelayanan Bea dan Cukai Tipe Madya Pabean A Marunda cenderung berusaha menyesuaikan diri dengan kondisi yang terjadi pada saat pelaksanaan anggaran. Hal ini sejalan dengan prinsip normatif dalam teori institusional.

Untuk melakukan proses revisi anggaran Kantor Pengawasan dan Pelayanan Bea dan Cukai Tipe Madya Pabean A Marunda, menyiapkan persyaratan berupa dokumen pendukung, terdiri 


\section{JURNALKU}

Volume 1 No. 2, Juni 2021

atas (i) surat usulan revisi anggaran; (ii) matriks perubahan (semula-menjadi); (iii) ADK SAKTI DIPA revisi; (iv) DIPA petikan sebelum revisi; (v) konsep DIPA sesudah revisi dan lampiran hal III DIPA sesudah revisi; (vi) surat pernyataan tanggung jawab mutlak; dan (vii) Petunjuk Operasional Kegiatan (POK) sebelum revisi.

\section{Revisi RKA-KL dalam Rangka Penghematan Selama Masa Pandemi}

Revisi ketiga dilakukan pada bulan April 2020, yang merupakan tindak lanjut atau respons yang dilakukan oleh kuasa pengguna anggaran atas terjadinya pandemi Covid-19. Sehubungan dengan ditetapkannya Surat Menteri Keuangan nomor S-302/MK.02/2020 tanggal 15 April 2020, Pagu Belanja Kementerian Keuangan mengalami penyesuaian dari semula sebesar Rp43.511.223.211.000 menjadi sebesar Rp38.915.104.895.000.

Kantor Pengawasan dan Pelayanan Bea dan Cukai Tipe Madya Pabean A Marunda sebagai satuan kerja menetapkan revisi dalam rangka efisiensi anggaran dengan berkoordinasi dengan kantor pusat Direktorat Jenderal Bea dan Cukai, dengan melakukan perkiraan penyerapan anggaran pada setiap kegiatan dan perkiraan jumlah anggaran tidak terserap sampai dengan akhir periode tahun anggaran 2020. Kemudian, ditetapkan baseline penghematan untuk Kantor Pengawasan dan Pelayanan Bea dan Cukai Tipe Madya Pabean A Marunda sebesar 5\% dari pagu anggaran atau sebesar Rp 959.747.000 (sembilan ratus lima puluh sembilan juta tujuh ratus empat puluh tujuh ribu rupiah)

Sumber penghematan belanja dilakukan pada anggaran yang bersumber dari Rupiah Murni (RM), diutamakan bersumber dari belanja barang perjalanan dinas, belanja non operasional dan biaya rapat serta belanja barang lainnya yang terhambat akibat adanya pandemi Covid-19 atau dapat ditunda ke tahun berikutnya, belanja modal untuk kegiatan yang tidak prioritas yang terhambat akibat adanya pandemi Covid-19 atau dapat ditunda ke tahun berikutnya, atau diperpanjang waktu penyelesaiannya (dari single-year menjadi multi-years, dan yang proyek multi-years diperpanjang ke tahun berikutnya) dan anggaran yang diblokir pada tahun anggaran 2020.

Kebijakan penghematan belanja modal terhadap anggaran belanja modal diharuskan memenuhi kriteria: (i) anggaran belanja modal yang belum berproses; (ii) Sisa anggaran dari pengadaan yang sudah direalisasikan (hasil optimalisasi); (iii) anggaran belanja modal yang sedang dalam proses pengadaan di UKPBJ yang masih memungkinkan untuk dibatalkan berdasarkan pertimbangan dari UPPBJ dan tidak menimbulkan dampak hukum di kemudian hari.

Sedangkan mekanisme revisi yang dilakukan adalah dengan cara melakukan perubahan rencana penarikan dana pada halaman III DIPA dan melakukan pergeseran anggaran antar keluaran (output), antar kegiatan, antar satuan kerja, dan antar program dalam wilayah kerja Kantor Wilayah Direktorat Jenderal Perbendaharaan yang berbeda.

Di dalam proses revisi anggaran dalam rangka penghematan anggaran, kuasa pengguna anggaran menggunakan 3 tema revisi antara lain : (i) revisi anggaran dalam hal pagu anggaran berubah; (ii) revisi anggaran dalam rangka penyesuaian belanja Kementerian/ Lembaga Tahun Anggaran 2020; dan (iii) perubahan rencana penarikan pada halaman III DIPA.

Dampak yang terjadi dari dilakukannya penghematan adalah turunnya realisasi pengeluaran pada pos anggaran yang dilakukan penghematan, namun secara kolektif realisasi anggaran tidak terpengaruh karena secara tidak langsung pandemi Covid-19 juga menghemat beberapa pos anggaran seperti turunnya frekuensi perjalanan dinas, turunnya tagihan listrik karena diterapkannya sistem work from home, turunnya frekuensi kegiatan penyediaan kudapan rapat atau konsumsi karena rapat diadakan secara virtual dan lain-lain. Realisasi belanja pegawai pada bulan Mei 2020 adalah sebesar 1.317.502.783 (14,39\%) belanja barang sebesar 611.473 .874 $(7,59 \%)$ dan belanja modal sebesar 33.516 .000 (4,22\%).

Kebijakan yang diambil oleh kuasa pengguna anggaran sejalan dengan teori atribusi yang memberikan penjelasan bahwa perilaku individu dapat disebabkan pengaruh internal atau 


\section{JURNALKU}

Volume 1 No. 2, Juni 2021

pengaruh eksternal, serta teori institusional yang menyatakan bahwa organisasi memiliki kecenderungan untuk berusaha menyesuaikan diri pada harapan eksternal. Kebijakan yang diambil dipengaruhi oleh pihak eksternal (Kantor Pusat Direktorat Jenderal Bea dan Cukai) untuk melakukan revisi anggaran penghematan.

\section{Revisi Penambahan Akun Selama Masa Pandemi}

Pandemi Covid-19 yang di alami seluruh penjuru Indonesia memberikan dampak yang merugikan bagi kondisi perekonomian negara, oleh karena itu Kementerian Keuangan melalui Direktorat Jenderal Perbendaharaan menerbitkan Surat Direktur Jenderal Perbendaharaan Nomor S-369/PB/2020 tanggal 27 April 2020 perihal Pemutakhiran Akun Dalam Rangka Penanganan Pandemi Corona Virus Disease 2019 (Covid-19).

Berdasarkan informasi yang penulis peroleh dari narasumber, revisi penambahan memiliki fungsi ganda. Pertama, untuk memudahkan kegiatan, koordinasi, monitoring dan evaluasi kinerja, termasuk pergeseran anggaran antar unit organisasi, antar fungsi, dan/atau antar program dalam penanganan pandemi Covid-19, pengalokasian dana penanganan Covid19 dilakukan berdasarkan klasifikasi akun khusus Covid-19. Kedua, satuan kerja dalam melakukan perencanaan/pengalokasian/revisi DIPA dan pelaksanaan anggaran dalam rangka penanganan pandemi Covid-19 agar menggunakan klasifikasi akun khusus Covid-19.

Sebagai respons atas kebijakan strategis yang diambil oleh Kementerian Keuangan, kuasa pengguna anggaran melakukan revisi anggaran dalam rangka penambahan akun khusus Covid-19 pada bulan Juli 2020 dengan menambahkan anggaran pada akun 521131- Belanja Barang Operasional-Penanganan Pandemi COVID-19 diperlukan karena jangka waktu dari pandemi Covid-19 yang berlangsung lebih lama dari perkiraan awal, sehingga anggaran untuk memberikan pelayanan kesehatan, melakukan pengecekan terhadap kondisi daya tahan tubuh dan memberikan suplemen makanan kepada pegawai menjadi tidak mencukupi. Kondisi tersebut sejalan dengan pernyataan yang diungkapkan oleh Sirat (2017) yang dalam penelitiannya menyatakan bahwa salah satu tantangan terbesar proses penganggaran adalah penentuan besaran alokasi.

Penambahan akun 521841 - Belanja Barang Persediaan-Penanganan Pandemi COVID19 bertujuan untuk memberikan pembeda terhadap belanja barang yang dilakukan, karena sebelumnya belanja terhadap obat-obatan khusus penanganan covid dimasukan bersama dengan akun 521832 - belanja barang persediaan lainnya sehingga terjadi kesulitan saat pencatatan persediaan, oleh karena itu dilakukan penambahan akun agar mempermudah disaat pelaporan dan pencatatan persediaan,

Penambahan akun 522192 - Belanja Jasa-Penanganan Pandemi COVID-19 bertujuan untuk beradaptasi terhadap perkembangan pandemi Covid-19 karena rapid test dianggap sudah tidak efektif dalam mendeteksi kandungan virus ditubuh pegawai, oleh karena itu dilakukan penambahan akun khusus belanja jasa untuk pembelian PCR test serta untuk memberikan kemudahan dalam proses penganggaran dan pencatatan, karena sebelumnya belanja terhadap kebutuh PCR test dilakukan dengan menggunakan akun 521111 - Beban Keperluan Perkantoran dan 522141 - Beban Sewa, atas kesalahan ini Kantor Pengawasan Dan Pelayanan Bea Dan Cukai Tipe Madya Pabean A Marunda telah melakukan revisi atas surat perintah membayar terkait dan telah dicatat pada catatan atas laporan keuangan.

Kebijakan yang diambil oleh kuasa pengguna anggaran untuk menambahkan akun khusus penanganan Covid-19 sesuat dengan penerapan teori stewardship karena sebagai satuan kerja yang dipercaya untuk mengelola dan memanfaatkan sumber daya berupa anggaran, kuasa pengguna anggaran telah mengambil keputusan sesuai dengan tepat, karena dengan penambahan akun khusus Covid-19 pelayanan publik dan kesejahteraan pegawai dapat berjalan secara efektif dan efisien. 


\section{JURNALKU}

Volume 1 No. 2, Juni 2021

\section{Revisi Pagu Minus Selama Masa Pandemi}

Selama pandemi Covid-19 telah terjadi banyak perubahan signifikan terhadap penganggaran, realisasi anggaran dan pendapatan. Untuk memberikan penanganan atas kondisi yang terjadi Kepala Biro Perencanaan dan Keuangan melalui Sekretariat Direktorat Jenderal menyampaikan permintaan dokumen usulan revisi anggaran dalam rangka penyelesaian pagu minus belanja pegawai dan perubahan target penerimaan negara bukan pajak (PNBP) tahun anggaran 2020.

Kuasa pengguna anggaran melakukan perhitungan estimasi terhadap akun yang mengalami pagu minus pada akhir tahun anggaran serta melakukan revisi terhadap perubahan target penerimaan negara bukan pajak (PNBP) tahun anggaran 2020 yang dibebankan kepada satuan kerja, dengan hasil Penerimaan negara bukan pajak akun 425131 - Pendapatan Sewa Tanah, Gedung, dan Bangunan mengalami penurunan target menjadi Rp7.588.000 sedangkan akun 425122 - Pendapatan dari Penjualan Peralatan dan Mesin mengalami kenaikan target menjadi Rp150.000.000, dan akun 425911 - Penerimaan Kembali Belanja Pegawai Tahun Anggaran dihapuskan dari kewajiban untuk menyetorkan penerimaan negara bukan pajak.

Tabel 4. Revisi Estimasi Pagu Minus (dalam Ribuan Rupiah)

\begin{tabular}{|c|c|c|c|c|c|c|}
\hline $\begin{array}{l}\text { Kode } \\
\text { Akun }\end{array}$ & $\begin{array}{l}\text { Nama } \\
\text { Akun }\end{array}$ & $\begin{array}{c}\text { Pagu per } \\
\text { November } \\
2020\end{array}$ & $\begin{array}{c}\text { Realisasi s.d. } \\
\text { November } \\
2020\end{array}$ & $\begin{array}{c}\text { Gaji } \\
\text { Induk } \\
\text { Desember } \\
\mathbf{2 0 2 0}\end{array}$ & $\begin{array}{l}\text { Belanja } \\
\text { Pegawai } \\
\text { Lainnya }\end{array}$ & $\begin{array}{c}\text { Estimasi } \\
\text { Sisa } \\
\text { Anggaran } \\
\text { per } 31 \\
\text { Desember } \\
2020 \\
\end{array}$ \\
\hline 511111 & $\begin{array}{l}\text { Belanja } \\
\text { Gaji } \\
\text { Pokok } \\
\text { PNS }\end{array}$ & 6.221 .692 & 6.594 .375 & 514.438 & 4.000 & $(891.121)$ \\
\hline 511119 & $\begin{array}{l}\text { Belanja } \\
\text { Pembuatan } \\
\text { Gaji PNS } \\
\end{array}$ & 118 & 113 & 9 & 0,4 & $(4,4)$ \\
\hline 511121 & $\begin{array}{l}\text { Belanja } \\
\text { Tunjangan } \\
\text { Suami/Istri } \\
\text { PNS }\end{array}$ & 390.160 & 394.190 & 30.557 & 400 & $(35.007)$ \\
\hline 511122 & $\begin{array}{l}\text { Belanja } \\
\text { Tunjangan } \\
\text { Anak/PNS }\end{array}$ & 106.680 & 108.393 & 8.574 & 200 & $(10.487)$ \\
\hline 511123 & $\begin{array}{l}\text { Belanja } \\
\text { Tunjangan } \\
\text { Struktural } \\
\text { PNS } \\
\end{array}$ & 302.400 & 288.000 & 22.500 & & $(8.100)$ \\
\hline
\end{tabular}

Sumber: DIPA Revisi

Berdasarkan keterangan yang diperoleh dari kepala subaggian umum dan staff keuangan, bahwa akun 511111 - Belanja Gaji Pokok PNS yang di estimasikan akan mengalami pagu minus sebesar Rp891.121.000 akan dibayarkan melalui DIPA Kantor Pusat Direktorat Jenderal Bea dan Cukai, dan terhadap akun 511119 - Belanja Pembulatan Gaji PNS, 511121 Belanja Tunjangan Suami/Istri PNS, dan 511122 - Belanja Tunjangan Anak PNS dapat ditutup melalui pergeseran pagu internal.

Oleh karena itu dalam revisi pagu minus tahun anggaran 2020 Kantor Pengawasan Dan Pelayanan Bea Dan Cukai Tipe Madya Pabean A Marunda tidak melakukan revisi anggaran 


\section{JURNALKU}

Volume 1 No. 2, Juni 2021

dengan tema Revisi Anggaran dalam hal Pagu Anggaran berubah, namun dilakukan dengan tema revisi Anggaran dalam hal Pagu Anggaran tetap dan revisi administrasi pada halaman III DIPA untuk mengubah target pendapatan negara bukan pajak dan rencana penarikan dana bulanan.

\section{Penyajian dan Pengungkapan Laporan Keuangan}

Akun khusus penanganan Covid-19 disajikan sebagai belanja barang pada laporan realisasi anggaran dan disajikan sebagai beban barang dan jasa pada laporan operasional.

Berdasarkan keterangan yang diberikan oleh staff keuangan tidak diberikannya segmen khusus pada catatan atas laporan keuangan di laporan keuangan unaudited tahun anggaran 2020 disebabkan seluruh penganggaran terkait penanganan Covid-19 telah dilaporkan secara terperinci ke Kantor Pusat Direktorat Jenderal Bea dan Cukai dan di setiap triwulannya telah dilakukan monitoring terhadap akun khusus penanganan Covid-19 sehingga pelaporan terkait penanganan Covid-19 akan dibahas secara lebih lanjut pada laporan keuangan Kantor Pusat.

Realisasi belanja satuan kerja pada tahun anggaran 2020 adalah sebesar Rp13.584.041.090 atau 74 persen dari anggaran belanja sebesar Rp18.405.020.000. Jika dibandingkan dengan realisasi belanja tahun anggaran 2019, realisasi belanja tahun anggaran 2020 mengalami kenaikan sebesar 3,88 persen.

Realisasi Belanja Barang tahun anggaran 2020 dan 2019 adalah masing-masing sebesar Rp7.712.432.965 dan Rp8.634.859.883. Realisasi belanja barang tahun anggaran 2020 mengalami penurunan sebesar 11,86 persen dari realisasi belanja barang tahun anggaran 2019 . Pandemi Covid-19 menyebabkan terkendalanya beberapa realisasi belanja termasuk berkurangnya perjalanan dinas dan diberlakukannya sistem work from home dan work from office bagi pegawai pada tahun anggaran 2020.

Realisasi pendapatan untuk periode yang berakhir pada 31 Desember 2020 adalah sebesar Rp764.126.828.093 mencapai 131 persen dari estimasi pendapatan yang ditetapkan sebesar Rp584.403.729.000. Pendapatan KPPBC Tipe Madya Pabean A Marunda terdiri dari Pendapatan Perpajakan dan Pendapatan Negara Bukan Pajak.

Realisasi pendapatan perpajakan tahun anggaran 2020 mengalami penurunan sebesar 6,7 persen dibandingkan tahun anggaran 2019. Penurunan ini terjadi karena pandemi Covid-19 yang terjadi sejak bulan Maret 2020 sehingga pelayanan kepabeanan dan cukai mengalami transisi dari semula secara tatap muka menjadi berbasis aplikasi atau online. Selain itu pendapatan negara bukan pajak Kantor Pengawasan Dan Pelayanan Bea Dan Cukai Tipe Madya Pabean A Marunda mengalami kenaikan sebanyak 496,68 persen yang berasal antara lain dari pendapatan sewa dan pendapatan jasa.

Berdasarkan penjelasan yang telah dipaparkan penulis berpendapat bahwa penyajian dan pengungkapan pada laporan keuangan unaudited tahun anggaran 2020 Kantor Pengawasan Dan Pelayanan Bea Dan Cukai Tipe Madya Pabean A Marunda terkait dengan realisasi anggaran telah memadai, karena realisasi terkait belanja pegawai, belanja barang dan belanja modal telah disajikan secara lengkap, namun belum terdapat penyajian dan pengungkapan yang spesifik terkait akun khusus penanganan Covid-19. Pada prinsipnya tidak terjadi perbedaan dalam penyusunan laporan keuangan yang dikelola satker pada masa sebelum dan selama covid-19, tetapi terdapat akun tambahan covid mengenai realisasi belanjanya (Amalla dan Bawono, 2021).

\section{PENUTUP \\ Simpulan}

Berdasarkan hasil wawancara, observasi data dan studi kepustakaan yang telah dilakukan oleh penulis terhadap proses penggaran dan revisi RKA-KL selama masa pandemi Covid-19 pada Kantor Pengawasan Dan Pelayanan Bea Dan Cukai Tipe Madya Pabean A 


\section{JURNALKU}

Volume 1 No. 2, Juni 2021

Marunda yang telah diuraikan pada pembahasan di bab-bab sebelumnya, penulis dapat mengikhtisarkan beberapa simpulan penting.

Pertama, dalam proses penyusunan anggaran tahun anggaran 2020 Kantor Pengawasan Dan Pelayanan Bea Dan Cukai Tipe Madya Pabean A Marunda telah melaksanakan sesuai dengan Peraturan Menteri Keuangan Republik Indonesia Nomor 142/PMK.02/2018 Tentang Perubahan Atas Peraturan Menteri Keuangan Nomor 94/PMK.02/2017 Tentang Petunjuk Penyusunan Dan Penelaahan Rencana Kerja Dan Anggaran Kementerian Negara/Lembaga Dan Pengesahan Daftar Isian Pelaksanaan Anggaran. Berdasarkan seluruh dokumen yang disusun dan tata cara penyajiannya. Penyusunan anggaran tahun anggaran 2020 disusun dengan memperhatikan tujuan dan fungsi anggaran serta memperhatikan pengendalian terhadap anggaran yang diajukan dan melakukan klasifikasi anggaran yang sesuai.

Kedua, revisi anggaran pada tahun anggaran 2020 dilakukan dengan memperhatikan tata cara revisi anggaran tahun anggaran 2020 dengan memperhatikan kinerja anggaran terhadap realisasi dan jumlah pagu anggaran. Revisi anggaran dalam rangka penghematan anggaran untuk menghadapi pandemi Covid-19 dilakukan dengan melakukan pengurangan anggaran yang bersumber dari belanja barang langganan daya dan jasa, pemeliharaan peralatan dan mesin, perjalanan dinas operasional, belanja barang operasional lainnya dan belanja non operasional, serta belanja barang lainnya yang terhambat akibat adanya pandemi Covid-19 dan belanja modal untuk proyek-proyek/kegiatan yang tidak prioritas, yang terhambat akibat adanya pandemi Covid-19. Revisi anggaran dalam rangka penambahan akun khusus penanganan Covid-19 dilakukan dengan menambahkan akun 521131- Belanja Barang Operasional-Penanganan Pandemi COVID-19, akun 521841 - Belanja Barang PersediaanPenanganan Pandemi COVID-19 dan akun 522192 - Belanja Jasa-Penanganan Pandemi COVID-19, bertujuan untuk memudahkan dalam hal pelaksanaan kegiatan, koordinasi, monitoring dan evaluasi kinerja dalam penanganan pandemi Covid-19. Revisi anggaran dalam rangka pagu minus dilakukan karena terjadinya kekurangan anggaran pada akhir tahun anggaran 2020 pada akun belanja pegawai dan terjadinya budgetary slack atau atau kesenjangan anggaran yang terjadi karna perbedaan potensi pendapatan dengan target pendapatan, sehingga dilakukan revisi atas target pendapatan negara bukan pajak.

Ketiga, penyajian terhadap akun khusus penanganan Covid-19 di laporan keuangan tidak memiliki segmen khusus, disajikan sebagai belanja barang pada laporan realisasi anggaran dan disajikan sebagai beban barang dan jasa pada laporan operasional.

Saran

Berdasarkan penelitian yang dilakukan oleh penulis dan simpulan yang telah diuraikan, berikut beberapa saran yang dapat penulis berikan terkait pelaksanaan akuntansi anggaran selama masa pandemi pada KPPBC TMP A Marunda

Menambahkan penjelasan atau segmen khusus mengenai penanganan anggaran selama pandemi Covid-19 pada catatan atas laporan keuangan mengingat adanya penambahan akun khusus penanganan Covid-19.

Menyusun rencana kerja pada awal tahun dan melakukan estimasi terhadap rencana penarikan dana tiap bulannya pada awal tahun, yang kemudian di evaluasi setiap triwulannya sehingga perencanaan anggaran akan lebih tepat sasaran.

\section{DAFTAR PUSTAKA}

Alim, M. N. (2008). Efektivitas Perpaduan Komponen Anggaran Dalam Prosedur Anggaran: Pengujian Kontinjensi Matching. Jurnal Akuntansi dan Keuangan, Vol 10 No.2.

Amalla, A. D., \& Bawono, A. D. B. (2021). Peran Akuntansi Akrual Dalam Penyusunan Laporan Keuangan Pada Masa Pandemi Covid-19 (Studi Kasus Pada RS. Ortopedi Prof. Dr. R. Soeharso). Jurnal Mutiara Akuntansi, 6(1), 88-102. 


\section{JURNALKU}

Volume 1 No. 2, Juni 2021

Andy P Hamzah, N. A. (2004). Dasar-dasar Akuntansi Pemerintahan. Tangerang Selatan: STAN Press.

Atmodjo, S. Y. P., \& Akhmadi, M. H. (2021). Pelaksanaan Anggaran Prioritas Pemulihan Ekonomi Nasional Pasca Pandemi COVID-19 Pada Satker di Wilayah KPPN SURABAYA II. Kolaborasi: Jurnal Administrasi Publik, 7(2), 144-166.

Hasanah, N., \& Fauzi, A. (2016). Akuntansi pemerintahan. Jakarta: In Media.

Imron, E. E. (2019). Pengaruh Reviu RKA-K/L Oleh APIP Terhadap Efisiensi Alokasi Anggaran Kementerian Agama. Jurnal Anggaran dan Keuangan Negara Indonesia .

Jefri, R. (2018). Teori Stewardship Dan Good Governance. Jurnal Riset Edisi XXVI UNIBOS Makassar.

Lestyowati, J., \& Kautsarina, A. F. (2020). Implementasi Realokasi Anggaran Dan Refocussing Kegiatan Di Masa Pandemi Covid-19 Studi Kasus Bdk Yogyakarta. Dipresentasikan pada Simposium Nasional Keuangan Negara, 2(1), 424-439.

Marunda, K. P. (2020). Laporan Keuangan Semester II (Unaudited) Tahun Anggaran 2020. DKI Jakarta: Kantor Pengawasan Dan Pelayanan Bea dan Cukai Tipe Madya Pabean A Marunda.

Muhyiddin, M. (2020). Covid-19, New Normal, dan Perencanaan Pembangunan di Indonesia. Jurnal Perencanaan Pembangunan: The Indonesian Journal of Development Planning, 4(2), 240-252.

Peraturan Menteri Keuangan Republik Indonesia Nomor 102/PMK.02/2018 Tentang Klasifikasi Anggaran. (2018). DKI Jakarta: Kementerian Hukum dan Hak Asasi Manusia Republik Indonesia.

Peraturan Menteri Keuangan Republik Indonesia Nomor 117/PMK.02/2020 Tentang Perubahan Atas Peraturan Menteri Keuangan Nomor 39/PMK.02/2020 Tentang Tata Cara Revisi Anggaran Tahun Anggaran 2020. (2020). DKI Jakarta: Kementerian Hukum Dan Hak Asasi Manusia Republik Indonesia.

Peraturan Menteri Keuangan Republik Indonesia Nomor 142/PMK.02/2018 Tentang Perubahan Atas Peraturan Menteri Keuangan Nomor 94/PMK.02/2017 Tentang Petunjuk Penyusunan Dan Penelaahan Rencana Kerja Dan Anggaran Kementerian Negara/Lembaga Dan Pengesahan DIPA. (2018). DKI Jakarta: Kementerian Hukum Dan Hak Asasi Manusia Republik Indonesia.

Peraturan Menteri Keuangan Republik Indonesia Nomor 212/PMK.05/2019 Tentang Jurnal Akuntansi Pemerintahan Pada Pemerintah Pusat. (2019). Jakarta: Kementerian Keuangan Republik Indonesia.

Peraturan Menteri Keuangan Republik Indonesia Nomor 39/PMK.02/2020 Tentang Tata Cara Revisi Anggaran Tahun Anggaran 2020. (2020). DKI Jakarta: Kementerian Hukum Dan Hak Asasi Manusia Republik Indonesia.

Peraturan Pemerintah Republik Indonesia Nomor 71 Tahun 2010 Tentang Standar Akuntansi Pemerintahan. (2010). Jakarta: Sekretariat Negara Republik Indonesia.

Podrug, N. (2010). Stewardship Relations Within Management Hierarchy. EKONOMSKI PREGLED.

Sirat, A. F. (2017). Kajian Asimetri Informasi Dalam Penentuan Alokasi Anggaran.

Haikal, M. F. F. (2021, March). Refocusing Anggaran Di Masa Pandemi Covid-19. Presented at Conference on Economic and Business Innovation (Vol. 1, No. 1, pp. 774-782).

Sukarta, B. R. (2017). Pengaruh Kompetensi, Pemanfaatan Teknologi Informasi, Komitmen Dan Revisi Anggaran Pada Efektivitas Pengelolaan Anggaran Universitas Udayana. EJurnal Ekonomi dan Bisnis Universitas Udayana. 


\section{JURNALKU}

Volume 1 No. 2, Juni 2021

Suparman, N. (2021). Dampak Pandemi Covid-19 terhadap Pengelolaan Keuangan Negara. Indonesian Treasury Review: Jurnal Perbendaharaan, Keuangan Negara dan Kebijakan Publik, 6(1), 31-42.

Suyitno, A. (2020). Dampak Pandemi Terhadap Penyerapan Anggaran di Kantor Kementerian Agama Kabupaten Mojokerto. Jurnal Public Policy, 6(2), 67-74.

Undang-Undang Republik Indonesia Nomor 2 Tahun 2020 Tentang Penetapan Peraturan Pemerintah Pengganti Undang-Undang Nomor 1 Tahun 2020 Tentang Kebijakan Keuangan Negara Dan Stabilitas Sistem Keuangan Untuk Penanganan Pandemi Corona Virus Disease 2019. (2020, Mei 16). Jakarta, Daerah Khusus Ibukota, Indonesia: Kementerian Sekretariat Republik Indonesia.

Walidi. (2017). Kajian Pengelolaan Biaya Dalam Sistem Penganggaran.

Yeyen. (2013). Pengaruh Revisi Anggaran, Partisipasi Anggaran, Tingkat Kesulitan, Serta Evaluasi Dan Umpan Balik Terhadap Pencapaian Anggaran Yang Efektif.

Zamaro, R. T. (2019). Analisis Penghitungan Proyeksi Belanja Operasional Kementerian Negara dan Lembaga Untuk Penyusunan Pagu Indikatif. 